\title{
INFANT GROWTH DURING THE FIRST YEAR OF LIFE
}

\author{
Priscila Vitor Alves Ferreira ${ }^{1}$, Viviane Santos Leal ${ }^{1}$, Marcella Moura Câmara da Silva ${ }^{1}$, \\ Adriana de Oliveira Mukai ${ }^{1}$, Celso Luiz de Sá Rodrigues ${ }^{1}$, Ciro João Bertoli ${ }^{1}$, \\ Viviane Gabriela Nascimento ${ }^{2,3}$, Claudio Leone $^{3}$
}

DOI: http://dx.doi.org/10.7322/jhgd.103017

\begin{abstract}
Objective: The aim of this study was to describe and analyse the profile of growth in normal infants during the first year of life, including their patterns of weight and length, and the duration of breastfeeding. Methods: This is a retrospective cohort study conducted based on 85 records of infants who met the inclusion criteria. The total duration of breastfeeding was recorded along with weight and length at three ages: birth, 6 and 12 months. The data were analysed as Z-scores based on WHO (2006) using the software products MedCalc 12.0 and GraphPad Prism 6.0. Results: Although $76.5 \%$ of the infants showed a growth pattern compatible with WHO references at 12 months of age, the others presented as overweight as at risk of being overweight. A significant correlation was observed between birth weight and BMI Z-score at two ages: 6 months $(r=0.26 ; p=0.01)$ and 12 months $(r=0.32 ; p=0.002)$. A correlation between birth weight and length Z-score was also found at 6 months $(r=0.4034 ; p=0.0001)$ and 12 months $(r=0.3309 ; p=0.002)$. Birth length was also correlated with length Z-score at 6 months $(r=0.4829 ; p<0.0001)$ and 12 months $(r=0.3407$; $\mathrm{p}=0.0014)$. Breastfeeding duration did not show any correlation with anthropometric data at 6 and 12 months of age. Conclusion: The growth pattern of the sample during the first year of life was found to be appropriate or faster than normal. Growth pattern also seems to be influenced by anthropometric characteristics at birth, which does not depend on breastfeeding duration.
\end{abstract}

Key words: anthropometry, growth, nutritional status, breastfeeding.

\section{INTRODUCTION}

Somatic growth is complex and flexible, and thus is a variable process. The assessment of children's growth is considered one of the best health and nutrition indicators, reflecting the interaction of numerous environmental factors beyond individual factors ${ }^{1.2}$. The diet, health and nutritional status of the mother, and particularly the occurrence of gastrointestinal infections, are said to be the main determinant of a child's growth ${ }^{3}$, reflecting the conditions of health, hygiene and nutrition in a given population ${ }^{4}$.

The World Health Organisation (WHO), the Ministry of Health ( $\mathrm{MH}$ ) and the Brazilian society of Paediatrics (BSP), recommend the routine monitoring of growth in children, enabling the early diagnosis of possible nutritional deviations such as malnutrition, and being overweight or obese ${ }^{5}$.

This growth monitoring is usually accomplished through anthropometric assessment of weight and height, which is a simple, non-invasive and low-cost process that evaluates size, proportions and the composition of the human body in all age groups ${ }^{4}$. Children must be evaluated, if possible, on a monthly basis in their first year of life, every two months in the second year, and each three months in the third year; this assessment should persist semi-annually at subsequent ages ${ }^{6}$.

The potential of postnatal physical growth is determined by genetic factors (the intrinsic individual) and extrinsic factors, including socioeconomic and environmental conditions, nutrition and morbidity, as well as birth weight ${ }^{7.8}$.

A high birth weight has been associated with a higher risk of developing obesity ${ }^{9}$. A low birth weight, when a child becomes obese, has been linked to the increased central distribution of fat, decreased glucose tolerance and the emergence of metabolic syndrome $\mathrm{e}^{10.11}$.

Low birth weight and intrauterine growth restriction are usually accompanied by a quick and intense "catch-up" period of growth during the first year of life, but fast postnatal weight gain, especially during the first months of life, is a risk factor for future obesity ${ }^{12.13}$.

Evidence indicates that the rate of weight gain during the first months of life is determined by the

1 Departamento de Biociências, Faculdade de Medicina de Taubaté, Universidade de Taubaté (UNITAU), Taubaté (SP), Brasil.

2 Curso de Nutrição - Universidade Paulista - (UNIP) - São Paulo (SP), Brasil.

3 Departamento de Saúde Materno-infantil, Faculdade de Saúde Pública, Universidade de São Paulo (USP) - São Paulo, (SP), Brasil.

Corresponding author: Priscila Vitor Alves Ferreira. E-mail: priscilavaferreira@gmail.com

Suggested citation: Ferreira PVA, Leal VS, da Silva MMC, Mukai AO, Rodrigues CLS, Bertoli CJ, et al. Infant growth during the first year of life. Journal of Human Growth and Development. 25(2): 211-215. DOI: http://dx.doi.org/10.7322/jhgd.103017

Manuscript submitted: dec 29 2014. Accepted for publication: mar 062015. 
food type that a child receives. Epidemiological studies suggest that breastfeeding may act as a protective factor against childhood and adolescent obesity $^{14-19}$. The WHO recommends that exclusive breastfeeding is maintained for the six months of the infant's life, with the subsequent introduction of complementary foods associated with breastfeeding maintenance ${ }^{20}$.

The early introduction of solid foods before the fourth month of life has been linked with excessive weight gain in infancy and may be a predisposing factor to fatness ${ }^{21-23}$. On the other hand, the complementing of breast milk with other food should be established from the sixth month of life because, from that age, breast milk as a sole and exclusive food no longer meets all the needs of the child ${ }^{24}$.

The correct practice of complementary feeding is considered essential in fighting deviations in nutritional status, since it takes place between 6 and 24 months, a particularly critical period for growth. From the sixth month of life WHO recommends three meals of complementary foods in addition to breastfeeding ${ }^{25}$.

The supplementary feeding period, which is characterised by fundamental changes in a child's alimentation, can interfere with their growth rate, which, even in the medium and long term, can have consequences on the development and health of children ${ }^{26}$.

The aim of this study was to describe and analyse the profile of growth of normal infants during the first year of life and its relationship to weight and length, and the duration of breastfeeding in the city of Taubaté, São Paulo, Brazil.

\section{METHODS}

A retrospective and non-randomised study was conducted, from a convenience sample from the clinical records of normal infants born between 2010 and 2011 who had childcare follow up in the University Clinic Hospital of Taubaté, São Paulo, Brazil.

The study included healthy children between 0 and 12 months of age, of both sexes, with regular monitoring to obtain anthropometric data at least three times during the first year of life (birth, 6 and 12 months).

Birth length and weight data were collected. During the follow-up period, in the first year of life, weight and length data were collected to calculate body mass index (BMI). The total period of exclusive breastfeeding was also studied.

Children were excluded from the study who had chronic diseases or specific diseases of growth, extreme low weight at birth ( $<1,500 \mathrm{~g})$ and/or a length at birth of four standard deviations above or below the average.

Anthropometric data was transformed into $z$ scores, the 2006 WHO reference ${ }^{27}$.

The classification of nutritional status used the $z$ score of BMI (zBMI) criteria proposed in 2009, by the Ministry of Health in Brazil, for children under 5 years of age, which defines as very thin children with $\mathrm{zBMI}<-3$, with $\mathrm{zBMI} \mathrm{e}^{\prime \prime}-3$; thin at $<-2$, with zBMI $e^{\prime \prime}-2$ eutrophy and $d^{\prime \prime}+1$; at risk of being overweight at $1<2 \mathrm{e}^{\prime \prime} \mathrm{zBMI}$ as overweight at zBMI $>+2 d^{\prime \prime}+3$; and obese at $>$ zBMI +283 .

Microsoft Office Excel version 2007 software was used, to create the datasheet. The Pearson correlation coefficient $(r)$ and the linear regressions between anthropometric parameters and the BMI z score of infants were statistically analysed using the MedCalc 12.0 and GraphPad Prism 6.0 programmes.

\section{RESULTS}

From the selected records, 85 children met the inclusion criteria. Of these, $60.0 \%(n=51)$ of children were male and $40.0 \%(n=34)$ female.

It was found that $1.2 \%(n=1)$ had low weight, $76.5 \%(n=65)$ had appropriate weight, $15.3 \%(n=13)$ had overweight risk, $7.1 \%(n=6)$ were overweight. No child was assessed as suffering from obesity (Figure 1.)

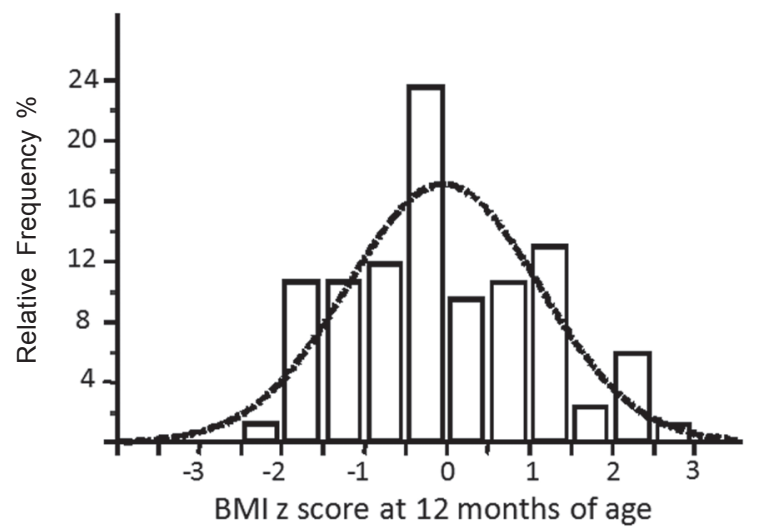

Figure 1: Distribution of children according to BMI at 12 months of age. Taubaté, São Paulo, Brazil, 2013.

By correlating birth weight and BMI z score data at 6 months of life, a significant positive correlation was found with $r=0.2645$ (95\% $C I=0.05447-0.4522$ ) and $p=0.0144$ (Figure 2).

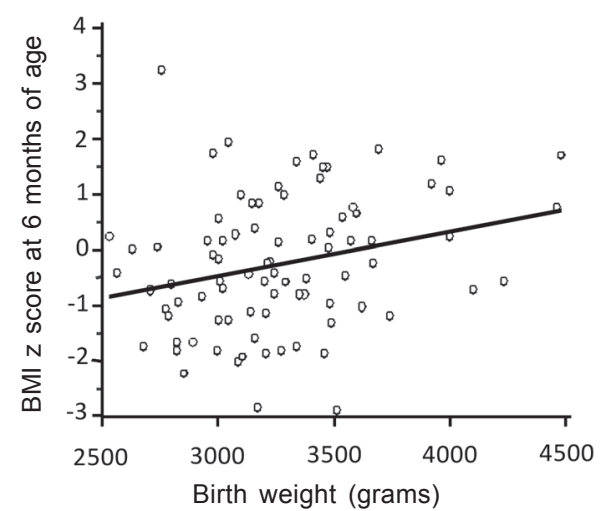

Figure 2: Correlation between birth weight in grams and BMI at 6 months of age. Taubaté, São Paulo, Brazil, 2013.

The correlation between birth weight and zBMI at 12 months of life was also positive and significant, at $r=0.3207$ (95\% CI = 0.1154-0.4997) and $p=0.0028$. (Figure 3 ). 


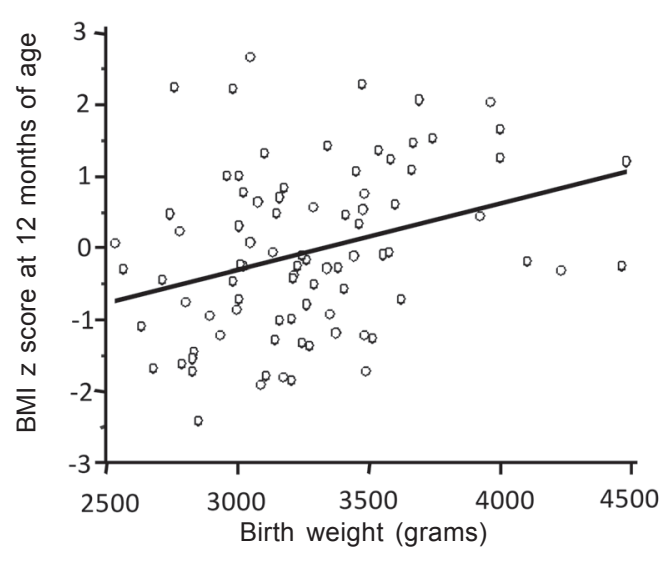

Figure 3: Correlation between birth weight in grams and BMI at 12 months of age. Taubaté, Sao Paulo, Brazil 2013.

Birth weight in relation to the $z$ score for age length at 6 months of life, $r=0.4034$ (95\% $\mathrm{CI}=0.2082-0.5677) \mathrm{p}=0.0001$, and at 12 months with $r=0.3309$ ( $95 \%$ CI $=0.1267-0.5082)$ $p=0.0020$ showed a significant positive correlation.

Figure 4 shows the correlation between $z$ score length at 6 months in birth length, with a $r=0.4829(95 \% \mathrm{CI}=0.2995-0.6319)$ and < p 0.0001, which is statistically significant. Figure 5 shows the correlation between the birth length and the $Z$ length score at 12 months of life with a $r=0.3407(95 \% C I=0.1375-0.5163)$ and $p=0.0014$, which is statistically significant.

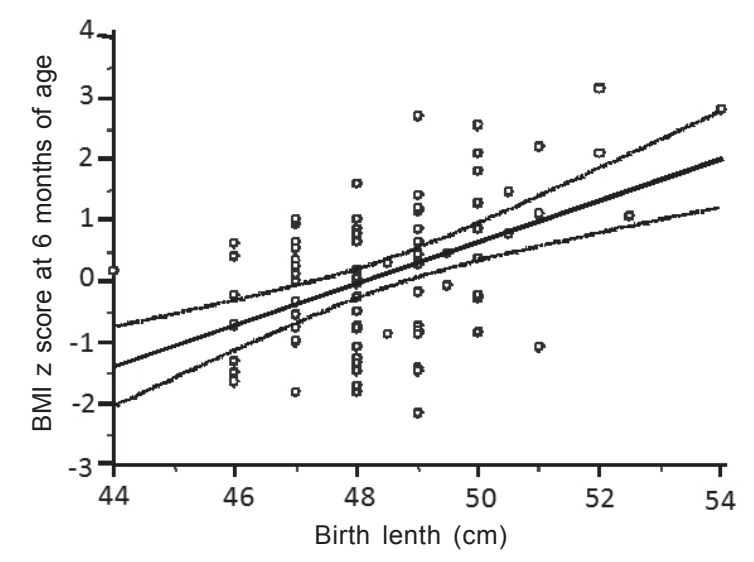

Figure 4: Correlation between length at birth and length at 6 months of age. Taubaté, Sao Paulo, Brazil, 2013.

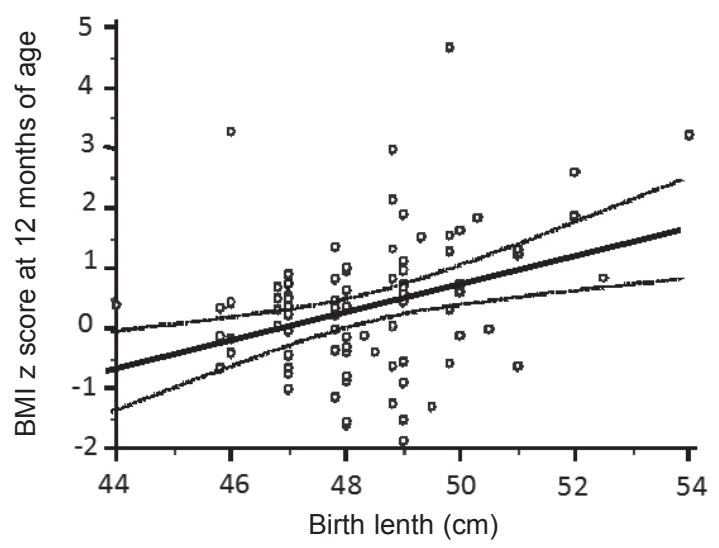

Figure 5: Correlation between length $\mathrm{z}$ score at birth and length to 12 months old. Taubaté 2013.
No significant statistical correlation was found for duration of breastfeeding, considering that 61 cases had this information, with the BMI $z$ score and the $z$ score of length to 6 months and 12 months of life.

\section{DISCUSSION}

Of the evaluated infants, $15.3 \%$ presented as at risk of being overweight, $7.1 \%$ were overweight and there was no child who was obesity. Birth weight data showed that the higher the weight the higher the tendency for an increase of BMI $z$ score or being overweight, in the first year of life.

The monitoring of the prevalence of this parameter is an important healthcare instrument for both the mother and child. The consequences of an unsuitable birthweight and the need for greater monitoring and care of them is highlighted consistently in the literature ${ }^{29}$.

It was noted that the greater their length at birth, the longer a child is at 6 and 12 months of age, a result that is in agreement with Weng et al. ${ }^{27}$

The monitoring of somatic growth in infants is important for the prevention of future problems, especially childhood obesity, which is today a major problem in public health ${ }^{30}$.

The Household Budget Survey (HBS 2002/ $03)^{31}$ showed that $11.9 \%$ of children up to one year in age presented in a percentile greater than or equal to $90 \%$ for weight in relation to their age, and a high prevalence of being overweight was found in this population in the present study.

Literature studies that show the relationship between birth weight and length related to age in normal infants were not found, preventing the comparison of results, which in this study showed a statistically significant positive correlation.

Direct and significant correlations were found between birth length and length at ages 6 and 12 months were found concordant with results from the studies of Westwood et al. ${ }^{28}$ and Posada et al. ${ }^{32}$, who claim that in the optimal conditions for life and the environment are the genetic factors exert the greatest influence on growth, and as a result infants who are born bigger would have a tendency to be bigger throughout their development, showing steady growth in the first year of life 29.32 .

Significant correlations were not found when relating breastfeeding duration to both BMI and length for age, in a meta-analysis of 29 studies that proved inconclusive about the protective effect of breastfeeding against overweight children; of the 29 studies analysed, 14 showed a strong protective effect, 9 a small protective effect, 5 did not detect a protective effect and 1 showed the opposite effect ${ }^{33}$, which demonstrates the need to undertake new and more extensive studies aimed at a better understanding of the possible protective effect of breastfeeding against being overweight and obesity in childhood.

Thus it can be concluded that infants with normal birth weight demonstrate suitable growth, according to the WHO 2006 references, during the first year of life, and that a higher birth weight tends 
to result in more intense growth during the first year of life, with a disproportionately greater increase of weight in relation to increased length.

\section{REFERENCES}

1. Bogin B. Patterns of Human Growth. Cambridge: Cambridge University Press; 1988.

2. Tanner JM. Fetus in to man: physical growth from conception to maturity. Revised ed. Cambridge: Harvard University Press; 1990.

3. Macchiaverni LML, Barros Filho AA. Perímetro cefálico: por que medir sempre. Medicina. Ribeirão Preto: 1998; 31(4): 595-609. DOI: http://dx.doi.org/10.11606/issn.21767262.v31i4p595-609

4. Bergmann GG, Garlipp DC, Silva GMG, Gaya A. Crescimento somático de crianças e adolescentes brasileiros. Rev Bras Saúde Mater Infant. 2009; 9(1): 85-93. DOI: http://dx.doi. org/10.1590/S1519-38292009000100010

5. Monteiro CA. Critérios antropométricos no diagnóstico da desnutrição em programas de assistência à criança. Rev Saúde Pública. 1984; 18(3): 209-17. http://dx.doi.org/10.1590/ S0034-89101984000300002

6. Centers for Disease Control and Prevention. Advance date from vital and health statistics. United States: National Center for Health Statistics [cited 2012 Sep 08] Available from: http://www.cdc.gov/nchs/products/ad.htm

7. Dewey KG. Cross-cultural patterns of growth and nutritional status of breast-fed infants. Am J Clin Nutr. 1998; 67(1): 10-7.

8. Maleta K, Virtanen S, Espo M, Kulmala T, Ashorn P. Timing of growth faltering in rural Malawi. Arch Dis Child. 2003; 88(7): 574-8.

9. Oken E, Gillman MW. Fetal origins of obesity. Obes Res. 2003; 11(4): 496-506. DOI: http:// dx.doi.org/10.1038/oby.2003.69

10. Hales CN, Barker DJ, Clark PM, Cox LJ, Fall C, Osmond $\mathrm{C}$, et al. Fetal and infant growth and impaired glucose intolerance at age 64. BMJ. 1991; 303(6809):1019-22.

11. Lithell HO, McKeigue PM, Berglund L, Mohsen $\mathrm{R}$, Lithell UB, Leon DA. Relation of size at birth to non-insulin dependent diabetes and insulin concentrations in men age $50-60$ years. BMJ. 1996; 312(7028): 406-10. DOI: http://dx.doi. org/10.1136/bmj.312.7028.406

12. Stettler N, Zemel BS, Kumanyika S, Stallings VA. Infant weight gain and childhood overweight status in multicenter, cohort study. Pediatrics. 2002; 109(2): 194-9.

13- Stettler N, Stallings VA, Troxel AB, Zhao J, Schinnar R, Nelson SE, et al. Weight gain in the first week of life and overweight in adulthood: a cohort study of European American subjects fed infant formula. Circulation. 2005; 111(15): 1897-903. DOI: http://dx.doi.org/10.1161/01.CIR.0000 161797.67671.A7

14. Bergmann KE, Bergmann RL, Von Kries R, Böhm $\mathrm{O}$, Richter R, Dudenhausen JW et al. Early determinants of childhood overweight and
On the other hand, there was no evidence that more prolonged breastfeeding was associated with better physical growth of the whole child. adiposity in a birth cohort study: role of breast feeding. Int J Obes Relat Metab Disord. 2003; 27(2):162-72. DOI: http://dx.doi.org/10.1038/ sj.ijo.802200

15. Gillman MW, Rifas-Shiman SL, Camargo Jr CA, Berkey CS, Frazier AL, Rockett $\mathrm{HRH}$, et al. Risk of overweight among adolescents who were breastfed as infants. JAMA. 2001; 285(19):2461-7. DOI: http://dx.doi.org/ 10.1001/jama.285.19.2461

16. Hediger ML, Overpeck MD, Kuczmarski RJ, Ruan WJ. Association between infant breastfeeding and overweight in young children. JAMA. 2001; 285(19): 2453-60. DOI: http://dx.doi.org/ 10.1001/jama.285.19.2453

17. Liese AD, Hirsch T, Von Mutius E, Keil U, Leupold W, Weiland SK. Inverse association of overweight and breastfeeding in 9 to 10 year old children in Germany. Int J Obes Relat Metab Disord. 2001; 25(11): 1644-50. DOI: http:// dx.doi.org/10.1038/sj.ijo.0801800

18. Toschke AM, Vignerova J, Lhotska L, Osancova $\mathrm{K}$, Koletzo B, Von Kries R. Overweight and obesity in 6-to-14 year-old Czech children in 1991: protective effect of breast feeding. J Pediatr. 2002; 141(6): 764-9. DOI: http://dx. doi.org/10.1067/mpd.2002.128890

19. Von Kries R, Koletzo B, Sauerwald T, Von Mutius E, Barnert D, Grunert V, et al. Breast feeding and obesity: cross sectional study. BMJ. 1999; 319(17): 147-50. DOI: http://dx.doi.org/ 10.1136/bmj.319.7203.147

20. Kramer MS, Kakuma R. The optimal duration of exclusive breastfeeding: a systematic review. Adv Exp Med Biol. 2004; 554: 63-77.

21. Baker JL, Michaelsen KF, Rasmussen KM, Sorensen TI. Maternal prepregnant body mass index, duration of breastfeeding and timing of complementary food introduction are associated with infant weight gain. Am J Clin Nutr. 2004; 80(6): 1579-88.

22. Kim J, Peterson KE. Association of infant child care with infant feeding practices and weight gain among US infants. Arch Pediatr Adolesc Med. 2008; 162(7): 627-33. DOI: http:// dx.doi.org/10.1001/archpedi.162.7.627

23. Taveras EM, Rifas-Shiman SL, Belfort MB, Kleinman KP, Oken E, Gillman MW. Weight status in the first 6 months of life and obesity at 3 years of age. Pediatrics. 2009; 123(4): 1177-83. DOI: http://dx.doi.org/10.1542/ peds.2008-1149

24. World Health Organization. Complementary feeding of young children in developing countries: a review of current scientific knowledge. Geneva: 1998.

25. Giugliani ERJ, Victora CG. Alimentação complementar. J Pediatr. 2000; 76(S3): S253-57.

26. Michaelsen KF. What is known? Short-term and long-term effects of complementary feeding. 
Nestle Nutr Workshop Ser Pediatr Program. 2005; 56:185-205. DOI: http://dx.doi.org/ $10.1159 / 000086300$

27. Weng SF, Redsell SA, Swift JA, Yang M, Glazebrook CP. Systematic review and metaanalyses of risk factors for childhood overweight identifiable during infancy. Arch Dis Child. 2012; 97(12): 1019-26. DOI: http://dx.doi.org/ 10.1136/archdischild-2012-302263

28. Westwood M, Kramer MS, Munz D, Lovett JM, Watters GV. Growth and development of fullterm non asphyxiated small-for-gestational-age newborns: follow-up through adolescence. Pediatrics. 1983; 71: 376-82.

29. Maia RRP, Souza JMP. Fatores associados ao baixo peso ao nascer em Município do Norte do Brasil. Rev Bras Crescimento Desenvol Hum. 2010; 20(3): 735-44.
30. Sibbald B. News @ a glance. CMAJ. 2004; 171(11): 1336. http://dx.doi.org/ 10.1503/ cmaj. 1041660

31. Instituto Brasileiro de Geografia e Estatística (IBGE). Pesquisa de Orçamento Familiar-2002/ 2003. Antropometria e analise do estado nutricional de crianças e adolescentes no Brasil. Rio de Janeiro: IBGE; 2006.

32. Posada $M E$, Rubén $M$, Esquivel M,Rubi $A$. Influencia de los factores socieconómicos sobre la talla de los niños. Rev Cubana Pediatr. 1984; 55: 597-604.

33. Mendes ACL, Queiroz JM, Melo ANL, Sureira TM, Pequeno NPF. Perfil nutricional de lactentes atendidos em unidade básica de saúde no Rio Grande do Norte. J Hum Growth Dev. 2014; 24(1): 16-23.

\section{Resumo}

Objetivo: Analisar o perfil do crescimento durante o primeiro ano de vida em lactentes normais e suas relações com o peso e o comprimento ao nascer e com o aleitamento materno. Método: Estudo de coorte retrospectiva com levantamento de dados de prontuários de 85 crianças que preencheram os critérios de inclusão. Registrou-se com peso e comprimento ao nascer, aos 6 e 12 meses de vida, e o tempo total de aleitamento materno. Os dados de crescimento foram analisados em escores z com base na referência da OMS (2006), utilizando os softwares MedCalc 12.0 e GraphPad Prism 6.0. Resultados: Aos 12 meses de vida 76,5\% dos lactentes apresentavam valores de crescimento compatíveis com o referencial da OMS, enquanto os demais estavam em risco de sobrepeso e sobrepeso. Observou-se correlação entre o peso de nascimento e o escore $z$ do Índice de Massa Corporal aos 6 meses $(r=0,26 ; p=0,01)$ e aos 12 meses $(r=0,32 ; p=0,002)$ e também com o escore $z$ do comprimento para idade aos $6(r=0,4034 ; p=0,0001)$ e 12 meses $(r=0,3309$; $p=0,0020)$. O comprimento ao nascer também mostrou correlação com o escore $z$ de comprimento aos $6(r=0,4829 ; p<0,0001)$ e 12 meses $(r=0,3407 ; p=0,0014)$. A duração do aleitamento materno não evidenciou correlação com os dados antropométricos dos 6 e 12 meses de idade. Conclusão: O crescimento alcançado durante o primeiro ano foi adequado ou acima do mesmo, sendo influenciado pelas características antropométricas ao nascer, independentemente da duração do aleitamento materno.

Palavras-chave: antropometria, crescimento, estado nutricional, aleitamento materno. 